\title{
A tradução para a criança e para o jovem: a prática como base da reflexão e da relação profissional
}

\author{
João Azenha Junior*
}

\begin{abstract}
This article deals with the attempt of systematizing my experience as translator of literature written for children and young people. On the basis of some considerations about aspects shared by both, the production and the translation of this kind of literature, this article presents a number of examples taken from translations of German texts into Brazilian Portuguese. Consequences concerning the importance of concepts like interaction and creativeness in translation are then briefly discussed. A claim for a more systematic consideration of the question by Translation Studies and for a special position to be occupied by this genre of texts in the professional field is the background of the article.
\end{abstract}

Keywords: translation of literature for children and young people; interaction; creativeness.

Zusammenfassung: Die vorliegende Arbeit stellt den Versuch dar, meine Erfahrungen als Übersetzer von Kinder- und Jugendliteratur zu systematisie-

João Azenha Junior é Professor Doutor junto ao Departamento de Letras Modernas da FFLCH-USP e atua na área dos Estudos da Tradução acoplados ao ensino de alemão como língua estrangeira e de literaturas de expressão alemã. $O$ autor agradece aos pareceristas deste artigo por sua leitura atenciosa e pelas valiosas sugestões, incorporadas - no limite do possível - ao escopo deste trabalho. 
ren. Von Aspekten ausgehend, die sowohl für die Produktion als auch für die Übersetzung von Kinder- und Jugendliteratur von entscheidender Bedeutung sind, werden Begriffe wie Interaktion und Kreativität bei der Übersetzung dieser Textsorte kurz erörtert. Dies geschieht anhand von Beispielen, die vom Deutschen ins brasilianische Portugiesische übersetzt wurden. Forderungen nach einer systematischeren Berücksichtigung dieser Frage seitens der Übersetzungstheorie und nach einer besonderen, noch zu definierenden Stelle für diese Übersetzungsart in der Berufspraxis liegen dem Beitrag zugrunde.

Stichwörter: Übersetzung von Kinder- und Jugendliteratur; Interaktion; Kreativität.

Palavras-chave: Tradução de literatura para a criança e o jovem; interação; criatividade.

$\mathrm{Ah}$ ! Tu, livro despretensioso, que, na sombra de uma prateleira, uma criança livremente descobriu, pelo qual se encantou, e, sem figuras, sem extravagâncias, esqueceu as horas, os companheiros, a merenda.

Cecilia Meireles

A tradução para jovens e crianças, a despeito de uma demanda elevada no mercado editorial brasileiro e mundial, ainda é relativamente pouco explorada e desenvolvida como tema específico pelos Estudos da Tradução no Brasil e no cenário internacional. ${ }^{1}$ Num campo teórico e disciplinar ainda em consolidação, a experiência de tradutores ganha relevância para a sistematização de uma moldura conceitual própria para a questão. É assim que, neste trabalho, a base da experiência de traduzir constitui o alicerce das

1 Cf. OitTinen (1998) e Dias (2001). Tal afirmação, contudo, deve ser entendida do ponto de vista de um tratamento teórico mais sistemático, pois referências às dificuldades oriundas desse tipo de tradução já foram tratadas esporadicamente por vários autores, dentre os quais - à guisa de exemplo - por Hans Joachim STÖRIG em sua obra clássica Das Problem des Übersetzens, de 1963. 
reflexões desenvolvidas ${ }^{2}$ e a noção de teoria, por conseguinte, deve ser entendida no sentido de uma reflexão sobre essa prática. A adoção da perspectiva do tradutor, ao mesmo tempo em que justifica a ausência, neste estudo, de uma revisão exaustiva da bibliografia atinente ao tema da literatura infantil e juvenil (daqui para frente LIJ), tem o objetivo de contribuir para elevar o patamar em que se encontra a reflexão sobre questões de literatura infantil e juvenil especificamente relacionadas com a prática de tradução.

À base da experiência soma-se um outro aspecto: o da amplitude do conceito de tradução de LIJ. O termo "tradução de literatura infantil e juvenil" estará sendo empregado nas reflexões desenvolvidas neste trabalho num sentido amplo, que abarca não apenas a produção literária para o jovem e a criança em sentido estrito, mas também todo e qualquer texto produzido ou traduzido para esse mesmo público: por exemplo, livros e softwares de cunho predominantemente didático, textos de suplementos especiais de jornais de grande circulação - os chamados textos de vulgarização de conhecimento -, assim como uma gama variadíssima de outros textos, que guardam entre si a característica de terem sido pensados e escritos para um público específico: “(...) mais do que uma 'literatura infantil', existem "livros para crianças”" (MeIreles 1951: 26).

Com efeito, a observação da realidade ensina que o conceito de LIJ abrange uma enorme diversidade de textos: só para citar alguns exemplos extraídos dos trabalhos de tradução listados ao final deste artigo, a série $O$ pequeno vampiro, da psicóloga alemã Angela Sommer-Bodenburg, conta a história da amizade entre um vampiro adolescente e um menino, a partir do que a autora procura trabalhar, sob o pano de fundo de conceitos da Psicologia, os medos das crianças: medo da morte, de cerimônias fúnebres, de caixões, de cemitérios, vampiros etc.; em $O$ mundo de Sofia, de Jostein Gaarder, uma espécie de thriller divide a cena com lições ministradas por um professor misterioso sobre a história da filosofia. Também em Por onde

As Referências Bibliográficas trazem, sob a rubrica "Títulos de LIJ traduzidos pelo autor deste artigo”, uma lista dos trabalhos que realizei neste domínio para editoras de São Paulo. 
você andou, Robert?, Hans-Magnus Enzensberger faz uma viagem do presente para o passado, do século XX ao século XVII, recriando passagens da história mais recente do homem e, ao mesmo tempo, revisitando a história dos meios de comunicação. Para o tradutor, a conseqüência imediata dessa diversidade de tipos textuais reunidos num grande grupo de textos destinados ao público infantil e juvenil é a de refletir e de realizar pesquisas em diferentes níveis, a fim de resguardar, de um lado, a acuidade conceitual e a ancoragem histórica, e de buscar, de outro, uma forma de expressão que faça com que o leitor dessas obras delas desfrute "se esquecendo dos companheiros e da merenda", conforme nos lembra Cecília Meireles no texto da epígrafe. Reconhecer tal diversidade e habituar-se a ela reduz o risco de o tradutor projetar, em seu trabalho, uma imagem estereotipada do texto escrito ou traduzido para o jovem e a criança e de ignorar as características específicas do material com o qual trabalha, sem refletir sobre a função que a tradução pode - e, muitas vezes, deve - assumir na cultura de chegada.

Um terceiro aspecto decisivo para o trabalho aqui desenvolvido diz respeito à natureza mesma da relação entre a instância de produção do texto e a instância de recepção:

... o processo de escritura e tradução de literatura infantil e juvenil é assimétrico. Ou seja, são adultos que escrevem e traduzem para "nãoadultos" (DiAs 2001: 7).

Essa assimetria, marcada pelas diferenças de experiência e de vivência do mundo real e ficcional, é considerada aqui um traço distintivo da tradução de LIJ. Não que outras características, mencionadas adiante para se caracterizar esse tipo específico de tradução, não sejam importantes: por exemplo, as escolhas de itens lexicais acessíveis à compreensão do público destinatário, o emprego de estruturas sintáticas condizentes com tais escolhas, o diálogo do texto com as ilustrações, os jogos e brincadeiras com a linguagem, que marcam o caráter lúdico dessas obras, entre tantos outros. Todos eles, de fato, podem ser encontrados na tradução de outros tipos de texto e não poderiam ser empregados aqui exclusivamente para se delimitar o escopo da questão. Na produção e na tradução de LIJ, porém, tais recursos assumem uma função de sustentação da assimetria mencionada, ora pro- 
movendo o alcance dos objetivos pretendidos para a obra e garantindo, assim, sua aceitação junto ao público, ora operando em sentido contrário, dependendo da conscientização, em maior ou menor escala, que o(a) autor(a) tem da natureza assimétrica que marca o processo de escritura de LIJ:

De modo que, em suma, o "livro infantil", se bem que dirigido à criança, é de invenção e intenção do adulto. Transmite os pontos de vista que este considera mais úteis à formação de seus leitores. E transmite-os na linguagem e no estilo que o adulto igualmente crê adequados à compreensão e ao gosto de seu público (MeIRELEs 1951: 35).

A sobreposição de perspectivas, já tão claramente observada por Cecília Meireles na década de 1950, possui o seu correlato na determinação do marco teórico envolvendo trabalhos que versam sobre a tradução de LIJ. Com efeito, a base da experiência de escrever (e de traduzir), a diversidade e o hibridismo dos textos escritos para jovens e crianças (quer dizer, a gama variada do que lhes pode ser "mais útil à formação") e a consideração sistemática do leitor (ou do que se imagina dele) como elemento diferenciador comprometem o marco teórico no qual se fundamentam as considerações sobre a tradução de LIJ primeiramente com os estudos culturais e funcionais da tradução. A tal aporte vêm se somar, cooperativamente, conceitos e métodos de outras vertentes teóricas: a Estética da Recepção, os Estudos de Cultura, a Teoria dos Polissistemas, a Teoria da Comunicação (sobretudo para os aspectos semióticos e para estudos sobre o perfil de públicos destinatários), mas também a Pragmática Contrastiva (para o emprego de recursos verbais em situações específicas), os aspectos poéticos da tradução (para o trabalho com versos, jogos de palavras e recriação de metáforas), questões de estilística entre tantas outras. Em resumo: a complexidade do gênero de textos aqui enfocados estabelece forçosamente zonas de intersecção com diversas áreas, todas elas de maior ou menor importância para o tratamento do tema. Resulta daí o fato de que, em se tratando de estudos sobre a tradução de LIJ, não será uma única teoria de tradução a dar conta a priori do problema, mas sim uma conjugação de conceitos e procedimentos metodológicos oriundos de diferentes vertentes.

Assim, extrapolaria os limites de um único artigo um tratamento mais denso de questões teóricas oriundas dos (poucos) exemplos aqui apontados, pois cada exemplo poderia ser considerado a partir de mais de uma 
perspectiva teórica. É claro que por detrás da preocupação que motivou a redação deste trabalho - a constatação de uma defasagem entre o tratamento dispensado tanto pela teoria quanto pelas relações do universo profissional à questão, de um lado, e a intrincada natureza do trabalho de tradução de LIJ em si, de outro - estão questões teóricas gerais contempladas amiúde por teorias consagradas. Contudo, a oferta de exemplos neste trabalho tem tão somente o intuito de, ao se pontuarem alguns resultados da experiência de UM tradutor, confirmar que o acúmulo da experiência de traduzir pode ilustrar - e, também, relativizar - alguns aspectos contemplados na teoria e estabelecer uma base para a sistematização da reflexão sobre o tema e para a formulação de sugestões que possam alterar o patamar em que se encontram as relações profissionais envolvendo autores, editoras e tradutores.

Das considerações anteriores parece ficar claro que o ponto de partida para a definição de uma estratégia de trabalho com textos produzidos quer dizer, escritos originalmente ou traduzidos - para o jovem e a criança não está apenas nas características do texto-em-si, tomado isoladamente, desvinculado de seu entorno, mas também e, sobretudo, na sua interação com quem escreve - o autor e o autor-tradutor - e com quem lê; na sua interação, enfim, com o entorno que lhe deu origem, com as referências ao universo eminentemente cultural que lhe serve de fundo. A interação constitui, assim, a base que viabiliza e justifica a tradução de LIJ; é ela que, ao colocar em discussão questões comuns que nos atingem a todos e sobre cujas soluções possíveis a criança e o jovem são convidados a refletir desde muito cedo, coloca o diálogo na base do trabalho com esse tipo de texto desde tempos imemoriais: primeiramente na tradição oral, depois no meio escrito e, mais recentemente, no ambiente eletrônico, virtual. É a interação, também, que justifica a escritura e a reescritura desse tipo de texto que, como qualquer outro, não está imune às transformações do tempo e dos hábitos e costumes de seus leitores. Por sua vez, esse fundo comum, na passagem da abstração à concretização em textos, vem revestido de uma ancoragem lingüístico-cultural mais específica, que contamina a linguagem e determina os contornos das noções e conceitos enfocados:

Quem traduz, leva para o interior do seu trabalho sua herança cultural, sua experiência como leitor e - no caso da tradução de livros 
infantis - também a imagem que faz das crianças. Surge daí um diálogo, de que tomam parte o leitor, o autor, o ilustrador, o tradutor e o editor (OitTINEN 1998: 250). ${ }^{3}$

No quadro dessa noção complexa e dinâmica, de que participam tantos agentes, a determinação das fronteiras entre a literatura infantil e a nãoinfantil não pode ser derivada, portanto, de características intrínsecas ao texto isolado, mas construída na interação mediada pelo autor e, no caso da tradução, pelo tradutor. Os trabalhos de MeIreles (1951) e CoELHo (1993), embora distanciados entre si em mais de quatro décadas, concordam em que é de mesma natureza o conteúdo das obras de LIJ e das obras da literatura não-infantil:

São as crianças, na verdade, que o delimitam [o conceito de literatura infantil], com a sua preferência. Costuma-se classificar como Literatura Infantil o que para elas se escreve. Seria mais acertado, talvez, assim classificar o que elas lêem com utilidade e prazer. Não haveria, pois, uma Literatura Infantil a priori, mas a posteriori (MEIRELES 1951: 26).

Em essência, sua natureza [da literatura infantil] é a mesma da que se destina aos adultos. As diferenças que a singularizam são determinadas pela natureza do seu leitor/receptor: a criança (CoELho 1993: 26; cit. em Dias 2001: 34).

A despeito disso, porém, a relação entre os textos escritos e traduzidos para o jovem e a criança parece ser marcada de forma negativa em relação aos textos escritos e traduzidos para o público não-infantil:

As relações da literatura infantil com a não-infantil são tão marcadas, quanto sutis. Se se pensar na legitimação de ambas através dos canais convencionais da crítica, da universidade e da academia, salta aos olhos a marginalidade da infantil. Como se a menoridade de seu pú-

3 Wer übersetzt, bringt sein kulturelles Erbe, seine Lesererfahrung und - bei der Übersetzung von Kinderbüchern - auch sein eigenes Bild von Kindern mit ein. Dabei entsteht ein Dialog, an dem die Leser, der Autor, der Illustrator, der Übersetzer und der Verleger beteiligt sind. 
blico a contagiasse, a literatura infantil costuma ser encarada como produção cultural inferior (LAJOLO \& ZilBERMANN 1985: 11).

Essa condição de marginalidade, no que respeita ao status da produção e da tradução de LIJ, manifesta-se, em primeiro lugar, no tratamento dispensado à questão pela teoria: apesar de as obras teóricas sobre teorias de tradução, salvo exceções, enfocarem apenas marginalmente a questão específica da LIJ, o volume de traduções desse tipo de texto é bastante considerável: em 2001, cerca de 19\% dos livros publicados para jovens e crianças no Brasil foram traduções. ${ }^{4} \mathrm{E}$ se, de um lado, a situação parece desfavorável à LIJ e, portanto, à sua tradução (e tradutores), de outro, a experiência de traduzir salienta a necessidade de um trabalho de conscientização a ser feito, no sentido de se mostrarem a importância e a gama de dificuldades desse tipo de trabalho e de se reivindicar uma mudança no paradigma de tratamento, por parte dos editores, para tradutores e traduções.

Em segundo lugar, essa "menoridade" encontra seu correlato nas relações e nas condições de trabalho de tradução, o que pode ser constatado na prática editorial não apenas no Brasil:

O menor valor pago por traduções de LIJ resulta provavelmente da crença das editoras de que não existe obrigatoriamente congeneridade entre a literatura infantil e juvenil e a literatura adulta e de que é mais fácil traduzir livros infantis e juvenis (RIEKEN-GERWING 1995: 165; cit. em Dias 2001: 10).

Vemos, portanto, que, se é verdadeira a posição de inferioridade ocupada por esse tipo de literatura, seus reflexos para o tradutor e a atividade de tradução são imediatos. De fato, tal diferença de status, constatada no plano da reflexão sobre a literatura infantil e juvenil, traz à luz e dá sustentação a

4 Os dados são da Fundação Nacional do Livro Infantil e Juvenil, Seção Brasileira do IBBY (International Board of Book for Young People). Informações atualizadas sobre este percentual não foram localizadas. Contudo, a julgar pelo crescimento do mercado editorial e pela crescente popularização das feiras e bienais de livros, tudo leva a crer que, de 2001 para cá, esse número tenha aumentado. 
uma outra assimetria: desta vez, a das relações entre quem encomenda o trabalho de tradução e aquele que o realiza. Se para a tradução da literatura escrita para um público não-infantil se pode identificar um seleto grupo de tradutores, via de regra ligados às academias e herdeiros de sólida fortuna crítica, para a tradução de LIJ os critérios que norteiam a escolha de tradutores não são claros. Mais do que isso: a pretensa "facilidade" da tradução desse gênero pode encobrir uma estratégia de contenção de custos de produção, que transfere para a revisão e o copidesque o texto-insumo do tradutor. E se, de um lado, tal atitude alimenta um círculo vicioso que pode ter resultados negativos para o leitor, por outro a reflexão que parte da prática sobre questões envolvidas na tradução de LIJ pode contribuir, num processo de retro alimentação, para alterar os contornos e as condições dessa mesma prática.

De volta às características distintivas dos textos escritos para jovens e crianças, e de sua tradução, se é o público leitor que ganha relevo nesse processo de interação multifacetado, então a ancoragem cultural desse público é fator determinante da estratégia de trabalho: escrever e traduzir para o jovem e a criança são atividades que refletem essa ancoragem com todas as suas implicações. Para além de questões culturais perceptíveis à primeira vista - hábitos, costumes, crenças, valores e outros -, também a relação com uma ideologia não pode ser desconsiderada e evidencia com clareza esse vínculo. Podemos pensar, por exemplo, no projeto nacionalista incorporado pela LIJ escrita e publicada no Brasil do início do século $\mathrm{XX}^{5}$ até por volta de $1945,{ }^{6}$ nas obras que registram a passagem de um Brasil rural a um Brasil urbano e na LIJ escrita em períodos de exceção, marcados pelo autoritarismo.

5 A tradução de Max und Moritz, de Wilhelm Busch, feita por Olavo Bilac em 1901, preserva ainda hoje sua vitalidade, passados mais de 100 anos de sua publicação. Contudo, POMARI (1999) defende a ênfase dada, na tradução de Bilac, ao aspecto moralizante da história dos dois meninos travessos, o que confirmaria seu vínculo com um ideal educacional de fins do século XIX e início do século XX no Brasil.

$6 \quad$ Cf. Lajolo \& Zilberman, 1986. 
Se a produção e a tradução de LIJ estão comprometidas com uma ideologia e um momento histórico, sua relação com o imaginário infantil funciona como uma via de mão dupla: ao mesmo tempo em que faz uso de elementos desse imaginário - num recorte que confirma, mais uma vez, o vínculo com uma tradição (recorrência a mitos, lendas e figuras do folclore, por exemplo) -, tal relação também interfere nesse mesmo imaginário, reforçando ou desmistificando estereótipos. Com o decurso da história, a crítica ao mundo dos adultos vai se transformando, por exemplo, de uma crítica ao autoritarismo de cunho sócio-político para uma crítica social e/ ou individual e psicológica (DiAs 2001: 25). A submissão a normas e horários, por exemplo, a escassez do tempo que priva as pessoas de um convívio mais prolongado, as ameaças da escalada da violência, das drogas, o tédio do isolamento e o peso da solidão, esses problemas - e muitos outros - manifestam-se, nos diferentes países, de formas diferentes e com ênfases diferenciadas: a crítica ao autoritarismo na relação pai/mãe-filho(a), por exemplo, pode parecer anacrônica a algumas culturas e perfeitamente pertinente a outras. ${ }^{7}$ Da mesma forma, conforme nos revela o exemplo a seguir, a correria do dia-a-dia e o conseqüente embotamento da sensibilidade e da criatividade parecem constituir um campo fértil de crítica e de inspiração para os autores de LIJ:

7 A reflexão sobre tais aspectos poderia, inclusive, servir de base para uma política de compra de direitos autorais de tradução. Nesse sentido, precisaria ser redimensionado o perfil dos agentes literários, de um lado, e do leitor que recebe da editora a incumbência de opinar sobre a obra, antes mesmo de serem adquiridos os direitos de publicação da tradução.

8 Neste trabalho, os exemplos extraídos das obras traduzidas mantêm a ortografia do alemão, tal como publicada. Da mesma forma, o texto traduzido foi transcrito literalmente da versão publicada. Nesse sentido, o autor agradece aos revisores que, num trabalho conjunto, cooperaram na busca por algumas das soluções aqui apresentadas. Seguem-se ao exemplo o título da obra e a página em que aparece a passagem citada. A referência bibliográfica completa pode ser encontrada ao final do trabalho. 
"(...) Was bist du von Beruf?" "Insbürogeher, sagte ich"."Aha” - sagte der König. "Also, du schläfst morgens ein und träumst den ganzen Tag, daß du ein Insbürogeher bist und daß du arbeitest, arbeitest und arbeitest. Und abends, wenn du ins Bett gegangen bist, wachst du auf und bist die ganze Nacht, was du wirklich bist. Mal ein Pilot und mal ein Ruderer und mal ein Wasweißich. Ist es nicht besser so herum?" Der kleine König Dezember, 21.
- (...) Qual é o seu trabalho?- Sou funcionário de escritório - disse eu.- Ah-ah! disse o rei. - Quer dizer, você adormece de manhã e sonha o dia todo que é um funcionário de escritório que trabalha, trabalha, trabalha. E à noite, quando vai para a cama, você acorda e durante toda a noite você é o que realmente é. Às vezes um piloto, outras vezes um remador, e outras um não-sei-mais-o-quê. Não é melhor assim? O reizinho Dezembro, 23.

Pensar, então, em "para quem se escreve" não é tarefa fácil, sobretudo se considerarmos que, salvo raras exceções, os livros são publicados e distribuídos, no Brasil, em escala nacional, a despeito de diferenças culturais marcantes entre as diversas regiões:

[Os conceitos de] criança e de infância são de definição bastante diferenciada. [A noção de] "Infância" é uma noção marcada social e culturalmente e pode ser vista tanto da perspectiva da criança, quanto da do adulto (OitTinen 1998: 251). ${ }^{9}$

Da dificuldade em se traçar um perfil do destinatário da produção e da tradução de LIJ decorre o perigo de se recorrerem a estereótipos, quando colocamos em confronto duas culturas distintas (nos exemplos aqui apresentados, a realidade brasileira e a alemã): as crianças alemãs seriam mesmo, como se costuma afirmar, mais "intelectualizadas" do que as brasileiras? Teriam elas, de fato, mais intimidade com a leitura? Tratar-se-ia aqui de diferenças intrínsecas ao público, ou de diferentes condições de recepção? Ou de ambas as coisas? Ainda que haja uma base comum entre essas diferentes crianças - uma base calcada, principalmente, na espontaneidade e

$9 \quad$ Kind und Kindheit wurden zu verschiedenen Zeiten ganz unterschiedlich definiert. ,Kindheit' ist eine gesellschaftlich und kulturell geprägte Vorstellung und sie kann aus der Perspektive des Kindes oder des Erwachsenen gesehen werden. 
numa certa inconseqüência saudável de que elas compartilham (DiAs 2001: 28) -, as diferenças no que respeita à recepção são significativas e isso tem influências para a tradução: assim como não podemos falar de uma "criança brasileira”, também podemos pensar nas diferenças entre crianças alemãs criadas sob a influência de preceitos e dogmas religiosos oriundos de diferentes profissões de fé (o meio-sul predominantemente católico e o meio-norte, protestante), jovens que viveram sua infância sob regimes marcados por ideologias diferenciadas (na ex-República Democrática Alemã e na ex-República Federal da Alemanha) e, também - pensando agora no grande espaço lingüístico alemão que inclui a Suíça e a Áustria -, em crianças e jovens que se desenvolvem em cantões isolados ou em grandes cidades. Teoricamente, portanto, seria possível buscar pontos de aproximação e distanciamento para os anseios e sonhos desses jovens e crianças das culturas alemã e brasileira, mas todo e qualquer termo de comparação teria de levar em devida conta diferenças históricas, usos e costumes etc. Teria de levar em conta, enfim, o entorno que marca a produção do texto de partida e o de chegada, num exercício de reflexão, para o tradutor, que vai de fora do texto para dentro dele, por assim dizer, e não o contrário.

Se colocamos anteriormente o público-alvo no centro dessa reflexão, temos de resgatar o conceito, também já mencionado, de "comunicação assimétrica": são adultos que escrevem ou traduzem para jovens e crianças. Quais as implicações disso? No processo de tradução de LIJ, trata-se de uma dupla projeção: o tradutor trabalha com a (sua) imagem daquilo que acredita ser a criança - na verdade, também uma projeção - imaginada pelo autor. E o texto traduzido, ao final das contas, pode convergir para ou divergir da criança imaginada e de seu mundo. A fim de se escapar das armadilhas desse jogo de projeções, vale a pena recuperar a noção de interação desenvolvida anteriormente (cf. nota 3) e considerar a tradução de textos para jovens e crianças um processo interativo, pensando-se desta vez no diálogo entre os agentes desse processo, cada um deles funcionando também como agente controlador das leituras e projeções dos outros.

Antes de passarmos a examinar alguns exemplos que ilustram esse processo interativo, cumpre dizer ainda que a consciência acerca dessas condicionantes de leitura e releitura está diretamente ligada à noção de interferência e à reflexão sobre a questão da fidelidade em tradução. No qua- 
dro da reflexão que vimos desenvolvendo até aqui, a tradução de LIJ é um campo fértil em que o tradutor é convidado, continuamente, a recriar. $\mathrm{E}$ estando as noções de recriação e criatividade ainda distantes da noção consensual de tradução, o problema que se delineia é o de saber 'até que ponto' o texto deixa de ser traduzido para ser 'adaptado'. Esta é uma questão importante e delicada, que não envolve apenas aspectos teóricos, mas também - e sobretudo - aspectos ligados às relações do mundo editorial. No Brasil, é comum encontrarmos livros traduzidos e retraduzidos a partir de sagas, lendas e mitos milenares com a indicação 'Thistória] recontada por...', ou então 'adaptada do original alemão por...'. Via de regra, as histórias 'recontadas' ou 'adaptadas' são aquelas que já se encontram no domínio público; são os clássicos ou 'tesouros' da literatura infantil e juvenil (os contos de Grimm e de Andersen, por exemplo, ou as sagas e mitos recolhidos da oralidade). Tais indicações presentes nas obras traduzidas, que podemos entender como ressalvas, não apenas reforçam a noção de que pode haver um limite, passível de demonstração objetiva, entre tradução e adaptação, como também parecem desconsiderar as características que marcam a tradução de LIJ: nesse domínio, todos os textos traduzidos são, forçosamente, recontados e adaptados ao seu ambiente de recepção. Trata-se aqui, em suma, de uma questão de grau e não de natureza.

Mas, então, como atingir esse público, em grande medida desconhecido? Como fazê-lo "se esquecer das horas, dos companheiros e da merenda," como nos diz Cecilia Meireles, senão recobrando-se para o universo ficcional ao menos uma parcela do prazer vivido fora do livro? Materializar no texto as possibilidades de brincadeiras, o caráter lúdico da vida e seus encantos: nisso parece estar o desafio de se traduzir para o jovem e a criança. ${ }^{10}$

\section{Alguns exemplos}

Os trechos selecionados a seguir não poderiam dar conta, nos limites deste artigo, de toda a gama de implicações derivadas das considerações anteriores. Eles têm aqui, como dissemos, tão somente o objetivo de ilustrar algumas dessas implicações e de chamar a atenção para o fato de que, na prática de

10 Cf. Azenha (1991, 1996). 
tradução da LIJ, muitas das decisões tomadas pelo tradutor têm de ser necessariamente negociadas entre as partes que atuam no processo de produção do livro traduzido, fato que reforça a reivindicação, formulada anteriormente, por um tratamento diferenciado para a tradução desse gênero de textos.

Considerando-se, então, a questão da linguagem propriamente dita, desempenham papel preponderante para a tradução de LIJ o poder de observação do tradutor (como ele acompanha a evolução do falar de crianças e jovens), seu cabedal de leituras de livros para jovens e crianças, o abandono de noções pré-concebidas sobre o modo como as crianças falam (no português do Brasil, por exemplo, a idéia de que o uso abundante de diminutivos em '-inho' e '-inha' caracterizariam esse tipo de linguagem) e, como conseqüência de tudo isso, seu domínio dos recursos expressivos no meio escrito, que traduzem esses usos. De um modo geral, podemos dizer que a linha mestra do tratamento da linguagem na tradução de LIJ está a meio caminho entre a simplificação e uma certa complexidade que garante a acuidade de informações e conceitos. Segue o exemplo abaixo:

Ich möchte Vampir werden, weil ich glaube, dass Vampire keine von Grund auf bösen Geschöpfe sind, wie in vielen Büchern und Filmen behauptet wird, sondern daß es von ihrem Charakter abhängt (genau wie bei den Menschen), ob sie ,gut" oder „böse“ sind. (...) Der kleine Vampir und die große Liebe, 43.

\begin{abstract}
Quero ser vampiro, pois acho que os vampiros não são essas criaturas malvadas que se mostram em livros e filmes, mas que depende do caráter deles (assim como no caso das pessoas) se são "bons" ou "maus". (...) O grande amor do pequeno Vampiro, 35.
\end{abstract}

Outros exemplos disso são as questões filosóficas tratadas em $O$ mundo de Sofia e as informações sobre outros povos e outros tempos em Por onde você andou, Robert?, duas das obras citadas no início deste trabalho. Como o público receptor está no centro das questões de tradução de LIJ, não é possível se escapar de uma certa aproximação com a linguagem do tempo para o qual se traduz, ressalvadas as limitações impostas pelo enredo e pelas brincadeiras com a linguagem da obra a ser traduzida.

Quanto aos jogos de linguagem, que resgatam o aspecto lúdico a que se fez referência na seção anterior, a operação de montar e desmontar a língua tem a função de ensinar, mas também de criticar o mundo adulto, à medida que convidam a uma reflexão sobre esse mesmo mundo. Ao desmontar uma metá- 
fora, por exemplo, e tentar entendê-la ao pé da letra, a criança reverte um paradigma, interrompe uma rede associativa, desfaz relações. Em $O$ dia do curin$g a$, de Jostein Gaarder, por exemplo, a personagem trava encontros, numa ilha imaginária, com cartas de um baralho. A cada encontro, cada carta profere uma sentença que reaparecerá mais tarde, numa festa organizada pelo Curinga. Acontece que, nessa festa, as cartas desfilam por naipes e na seqüência do baralho; assim, a frase traduzida isoladamente, ao longo de todo o livro, precisa estar ligada à frase da carta precedente, e também à da posterior, formando um texto de cinqüenta e seis frases que, como texto, demanda ajustes para além do limite de cada frase. A ordem linear, portanto, é rompida e o trabalho de revisão requer ajustes que forçam o tradutor a localizar cada ocorrência e a revê-las em função de um conjunto.

São exemplos de alguns jogos mais complexos, envolvendo inclusive uma terceira língua estrangeira:

(...) Auch die Art, wie die Leute am Hof redeten, machte ihm zu schaffen. Er hatte sich zu früh gefreut, als er ankam und dachte, hier könnte er endlich wieder seine eigene Sprache sprechen. Aber so einfach war das nicht. Zum Beispiel durfte man nicht sagen: „Der Fürst will“ oder , ,der Fürst möchte“. Es hieß: „Seine Durchlaucht geruht zu befehlen“. Manchmal kam sich Robert wie in der Französisch-Stunde vor. Er mußte Wörter büffeln, die er noch nie gehört hatte. Woher sollte er wissen, was eine Gavotte war, eine Assemblé, ein Rentmeister oder ein Fideikommiß? Nicht einmal die gewöhnlichsten Dinge hießen hier so, wie Robert es gewohnt war. Ein Wohnzimmer konnte ein Salon sein, aber auch ein Boudoir, je nachdem, oder ein Kabinett oder sogar eine Salle de Compagnie... Wo warst du, Robert?, 176-177. (...)
O modo como se conversava na corte era outra coisa que irritava Robert. A sensação de alívio que ele experimentara na chegada, ao ver que ali poderia falar sua própria língua, depressa desapareceu. Falar a própria língua não era tão fácil assim. Por exemplo, não se podia dizer: "O Príncipe quer" ou "O Príncipe deseja...”. O certo era dizer: "Sua Alteza, o Príncipe fulano de tal, digna-se ordenar que...". Às vezes parecia que ele estava numa aula de francês. Tinha de enfiar na cabeça palavras que nunca ouvira. Como é que podia saber o que significava uma gavotte, uma assemblée, um maître de rente ou um fidéicommis? Nem as coisas mais comuns eram chamadas pelo nome a que Robert estava acostumado. Uma sala de estar podia ser tanto um salon como um boudoir, ou mesmo um cabinet, ou até uma salle de compagnie, dependendo do seu tamanho, mobília e função. Por onde você andou, Robert?, 166. 
O trecho refere-se ao momento em que Robert, em sua viagem através do tempo, chega à corte austríaca no século XVIII. Aqui, a escolha do léxico não pode almejar apenas à satisfação dos critérios de compreensão e de aceitação, por parte do público, mas também da reconstrução, na tradução, das relações de autoridade, da oposição formalidade e informalidade e de circunstâncias histórias que marcam a diversidade diatópica de uma 'mesma’ língua, além - é claro - da (breve) explicação que esclarece as várias formas, em francês, de uma sala de estar.

Nessa mesma linha de montar brincadeiras com a linguagem - ou com as diferentes línguas em contraste -, o problema para a tradução se agrava quando a proximidade das línguas envolvidas entre si na narrativa (no exemplo seguinte, o alemão e o holandês) é muito maior do que estas em relação à língua para a qual se traduz:

(...) "Kostbaar", hatte er gesagt. Das war nicht schwer zu verstehen. Überhaupt fiel Robert das Niederländische leicht. Er hatte sich bald davon überzeugt, daß die meisten Wörter dem Deutschen ziemlich ähnlich waren: rood, groen, geel, bruin, blawn, wit und zwart, das war doch kein Problem, und auch penseel und tekening waren leicht zu entziffern. Nur an das eingentümliche Raspeln im Rachen mußte er sich erst gewöhnen. Ein Maler war hier een schilder, und ein Bild een schilderij, und dabei mußte man das sch sozusagen ächzend aussprechen. Wo warst du, Robert?, 254.
(...) Kostbaar, ele dissera. Robert não demorou a entender o sentido da palavra, graças à sua semelhança com o adjetivo kostbar, do alemão, que significa "valioso". Aliás, ele estava achando fácil o idioma holandês, pois logo percebera que a maioria das palavras eram muito parecidas [sic] com as da sua língua. Rood [rot-vermelho], groen [grün-verde], geel [gellb-amarelo], bruin [braun-marron], blaww [blau-azul], wit [weiß-branco] e swart [schwari-preto] nenhuma delas era um problema para ele. Quanto a penseel [Pinsel-pincel] e tekening [Zeichnung-desenho], tampouco encontrava dificuldade em compreendê-las. Só faltava Robert se acostumar a pronunciar aqueles sons. Por onde você andou, Robert, 238.

Neste exemplo, em que a personagem Robert visita a Amsterdã do século XVII, ressalta-se o fato de que, na versão em português, ampliada por informações adicionais, procedeu-se a uma reescritura e também a um corte, a uma redução do texto de partida alemão. Não é difícil enxergar que a narrativa não poderia ser sobrecarregada por notas de rodapé, o que acabaria comprometendo o aspecto lúdico, mas também que não se poderia pro- 
ceder a todo momento a acréscimos - em cada viagem de Robert, Enzensberger 'brinca' com as dificuldades do garoto em aprender a língua falada no local -, que terminariam por tornar o texto traduzido muito mais extenso do que o texto de partida. Sobre este último aspecto, a responsabilidade por acréscimos e cortes é - ou deve ser - negociada entre tradutor e editora, que é a responsável, em última instância, pelo formato final do livro e também pelos seus custos de produção. No exemplo apontado acima, porém, a essência do jogo lingüístico, ficou preservada.

Não bastassem questões lingüísticas ligadas à proximidade e ao distanciamento sistêmico e cultural entre as línguas, o problema pode ser aguçado ainda pelo acréscimo de um elemento visual, não-verbal, como no exemplo seguinte:

\section{КИНО}

Das war die Rettung! Wenigstens für ein paar Stunden konnte er sich dort in der Dunkelheit aufwärmen, und niemand würde ihn bemerken. Wo warst $d u$, Robert?, 55.

\section{КИНО}

Quase Kino, como na língua alemã! Um cinema! Era a sua salvação! Pelo menos por algumas horas ele poderia se aquecer lá dentro, no escuro, sem que ninguém estranhasse sua presença. Por onde você andou, Robert?, 55.

Aqui, em plena Rússia dos anos de 1950, as expansões são a única forma de se estabelecer um elo capaz de vencer a distância entre texto e elemento não-verbal, de um lado, e entre as línguas e as culturas envolvidas: o russo, o alemão e o português do Brasil.

Para além dos jogos com palavras, a escolha lexical na tradução de LIJ pode tangenciar, também, domínios do léxico de especialidade, como nos dois exemplos que se seguem. Em ambos os casos, trata-se da visita de Robert a um vilarejo da Noruega do século XIX, onde ele faz amizade com um artista gravador em madeira:

(...) In der Bucht und am Kai sah Robert Segelschiffe und Boote liegen. Eines davon war ein Dreimaster. Winzig kletterten Matrosen in der Takelage herum und waren dabei, die Segel zu reffen.(...) Wo warst du, Robert?, 134.
(...) Na baía, e também no cais, Robert avistou botes e barcos a vela. Um deles tinha três mastros. Os marinheiros, minúsculos à distância, movimentavam-se junto ao cordame e se preparavam para desfraldar as velas. (...) Por onde você andou, Robert?, 128 (grifos meus). 
Das alles habe ich aus Europa mitgebracht, die Grabstichel, den Geißfuß, das Falzbein. Die Holzstöcke kommen aus Deutschland. Sie sind aus Buchsbaum oder Birne, das härteste Holz, das es gibt, quer zur Faser geschnitten. Wo warst du, Robert?, 138.
Eu trouxe tudo isso da Europa: o buril, a alcaprema, a dobradeira. As pranchas de madeira são da Alemanha. É madeira de bétula, a mais dura que existe, cortada de través em relação à fibra. Por onde você andou, Robert?, 131 (grifos meus).

Outra questão a ser enfrentada na tradução de LIJ diz respeito ao tratamento dispensado às referências que situam a narrativa no tempo e no espaço. Tais referências dizem respeito diretamente ao que comumente se convencionalizou chamar de adaptação: a substituição, no texto traduzido, de nomes próprios, topônimos, unidades de pesos e medidas entre outros. Tal procedimento, a despeito de aproximar o texto traduzido da realidade do leitor-receptor, tem a desvantagem de apagar a chamada 'cor local' da narrativa e de convidar o leitor da tradução a estabelecer redes associativas que podem estar muito distantes daquelas propostas no texto de partida: por exemplo, a substituição de uma variante dialetal do texto de partida por outra, aparentemente 'correspondente' na cultura de chegada, tem conseqüências para a configuração, na rede associativa do leitor, do espaço em que se passa a história.

Embora tenha sido prática amplamente adotada nesse tipo de tradução no Brasil das décadas de 1940 a 1950, ${ }^{11}$ o que se observa na prática editorial atualmente é um movimento no sentido de se manter, ao menos neste nível de referência, a estrangeiridade do texto: nos casos em que tais referências são essenciais para a caracterização do espaço, ou quando elas têm o suporte de ilustrações que não podem ser modificadas, a tendência é a de que sejam mantidas, o que propõe ao leitor o exercício de incluir no seu repertório de conhecimento uma série de informações sobre usos e costumes de outros povos:

11 Cf. Milton (2002) e Lajolo \& Zilberman (1986). Nesse contexto, a figura e a atuação de Monteiro Lobato como escritor, tradutor e editor surgem como um tema em si, que não poderia ser desenvolvido, ainda que superficialmente, nos limites deste artigo. Para um aprofundamento da questão, ver também Milton (2004) e Vieira (2001). 
“(...) Wohin gehst du jeden Tag nach dem Frühstück?“ „Ins Büro“ sagte ich. "Ich gehe die Corneliusstraße hinunter zum Gärtnerplatz, dann über die Blumenstraße und den Jakobsplatz zur Sendlinger Straße. Das mache ich jeden Tag, und abends gehe ich zurück immer derselbe Weg und immer dasselbe Büro. Der kleine König Dezember, 24.
- (...) Aonde você vai todos os dias depois do café?- Ao escritório - disse eu. - Desço a mesma rua até chegar à mesma praça, atravesso uma outra e mesma rua, depois uma outra e mesma praça, até chegar a uma outra e mesma rua. Faço esse trajeto todos os dias e à noite volto para casa. Sempre o mesmo trajeto, sempre o mesmo escritório. $O$ reizinho Dezembro, 26.

Neste exemplo, a opção adotada foi a de se resgatarem a monotonia e a mesmice do trajeto tomado diariamente pela personagem. As referências a nomes de ruas e praças da cidade de Munique foram apagadas, embora a referência à cidade se faça presente em outro momento do texto e a presença de ilustrações se incumba de estabelecer o vínculo da narrativa com a cidade alemã.

Até este ponto, parece ter ficado claro que a experiência de traduzir LIJ está intrinsecamente ligada à noção de criatividade em tradução; à recriação, em última análise. Nesse sentido, os aspectos poéticos da linguagem $^{12}$ talvez representem os pontos em que isso se expressa de forma mais eloqüente: a tradução de jogos verbais infantis, provérbios, trocadilhos e versinhos sublinham a experiência de recriar, conforme demonstram os dois exemplos apresentados a seguir:

"Willst du mich fragen insgeheim,sprich im Gedicht mit mir, im Reim,denn was man nicht in Versen spricht,versteh'ich nicht - versteh'ich nicht...

“(...),

Wenn mir die Frage gestattet ist,dann wüßt'ich gerne, wer du bist “(...),"

Nun nehm'ich dich wahr! "So versteh'ich dich klar!

"Die unendliche Geschichte, 106.
"Se queres falar-me sobre qualquer tema,

Deves fazê-lo em forma de poema.Pois aquilo que não escuto em verso,

Entendo sempre de modo diverso."

(...)

"Se esta curiosidade posso ter,quem és tu gostaria de saber."

(...)

"Queres saber quem é quem?

Agora já te entendo bem."

A bistória sem fim, $96 .{ }^{13}$

12 Cf. Laranjeira 1993: 161.

13 O livro $A$ bistória sem fim foi traduzido ao português originariamente por Maria do Carmo Cary e publicado pela Editorial Presença. Embora me tenham sido 
Poesie-Album von Anna Irmgard von Schlotterstein

(...)

Ach, wie schön das Leben ist, wenn das Blut so richtig fließt.

(...)

Wo man singt, da laß dich ruhig nieder,denn wer Blut hat, hat auch Lieder.

(...)

Reden ist Silber,

Bluten ist Gold.

Der kleine Vampir auf dem Bauernhof, 85-86.
Álbum de recordações de Ana Irmgard von Schlotterstein

(...)

Ah, como é bela a vida,

Quando o sangue escorre da ferida!

(...)

Fica ao lado daquele que canta,

Pois quem tem sangue seus males espanta!

(...)

A palavra é prata,

$\mathrm{O}$ silêncio é sangue.

O pequeno vampiro no sítio, 82-84.

Seja nas perguntas que Atreiú, a personagem de Michael Ende em $A$ bistória sem fim, endereça ao oráculo que só compreende o que lhe é perguntado em verso, seja no 'Álbum de Recordações' da vampirinha Ana, em que seus amigos e parentes registram 'conselhos' e palavras de afeto, o desafio da dimensão poética da linguagem está presente com freqüência na tradução de LIJ. Afinal, é ela - a dimensão poética - que resgata para o interior do texto o universo encantado que acompanha o leitor desde o berço, com as cantigas de ninar, passando pelas cantigas de roda das brincadeiras em grupo até chegar aos domínios da escola, com as técnicas de alfabetização. É ela, também, que instaura o vínculo mais profundo com as culturas e com as crenças e convicções populares; com o conhecimento armazenado e compartilhado, em última análise. Para o tradutor resta aqui o desafio de reconstruir esses elos, valendo-se para tanto do apelo à sua própria experiência, do seu poder de observação e do investimento num tipo de escritura que, com muita freqüência, está longe de sua lida cotidiana com a linguagem e dos ditames que marcam as relações de poder entre a instância que lhe encomenda o texto - a editora - e ele próprio.

atribuídos a revisão e o texto final da edição brasileira, todas as partes versificadas da obra foram traduzidas por mim a partir do original alemão. 
Um último aspecto merece ainda consideração neste sobrevôo por questões envolvidas na tradução de LIJ. Também ele, pelas limitações deste artigo, será apenas aludido. Trata-se da consideração de aspectos gráficos e tipográficos. Aqui, mais do que nos aspectos já mencionados, o trabalho do tradutor caminha pari passu com o do arte-finalista, responsável, no processo de produção do livro, pela inserção das ilustrações e por sua articulação com o texto. Tais aspectos vão desde a organização e a segmentação da narrativa, estabelecendo os planos de realidade e fantasia - por cores diferentes n' $A$ bistória sem fim, de Michael Ende, e por tipos gráficos diferentes em $O$ mundo de Sofia e n' O dia do curinga, de Jostein Gaarder - até à delimitação do espaço físico em que se devem inserir as opções de tradução:

Ilustração 1: Wo warst du, Robert?, 109

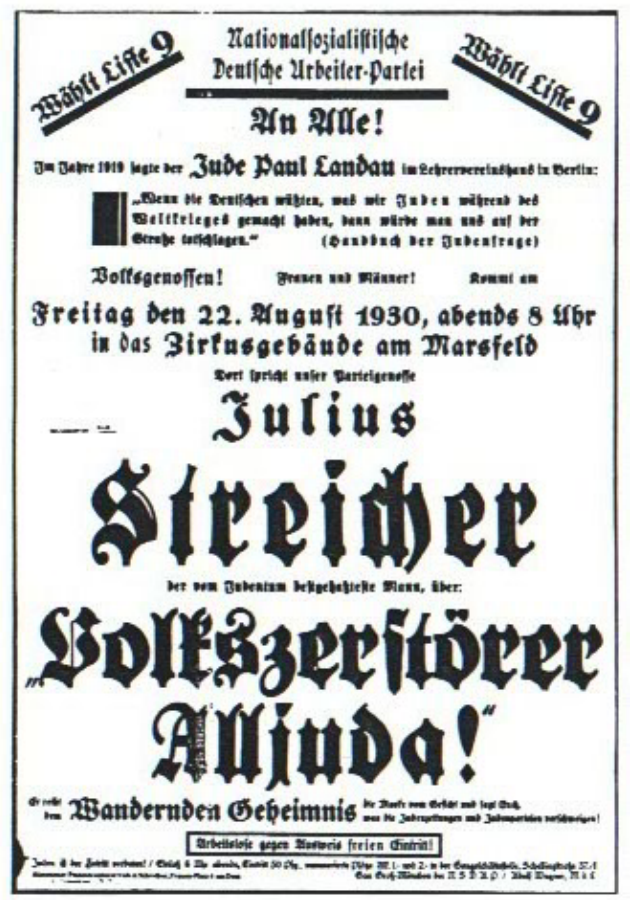

Ilustração 2: Por onde você andou, Robert?, 105

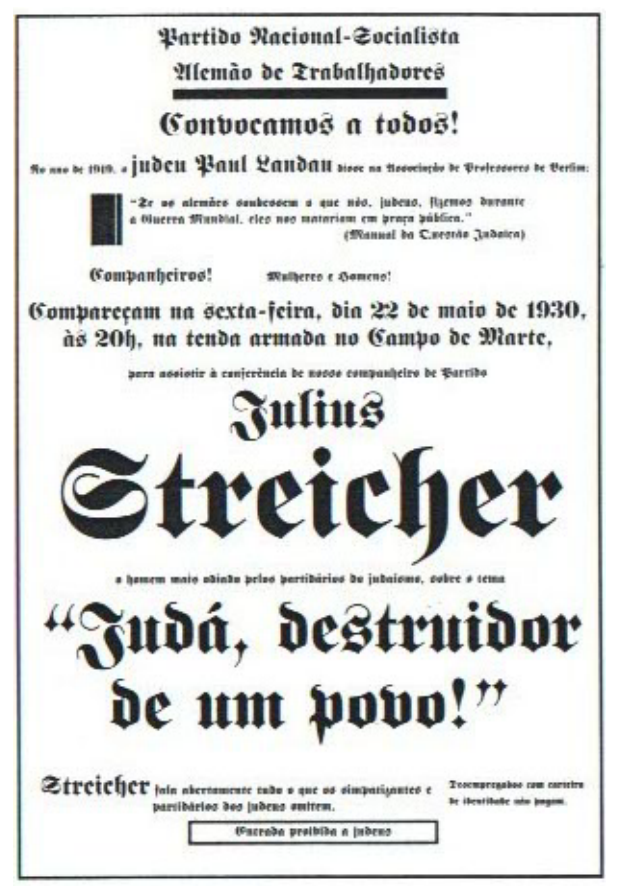




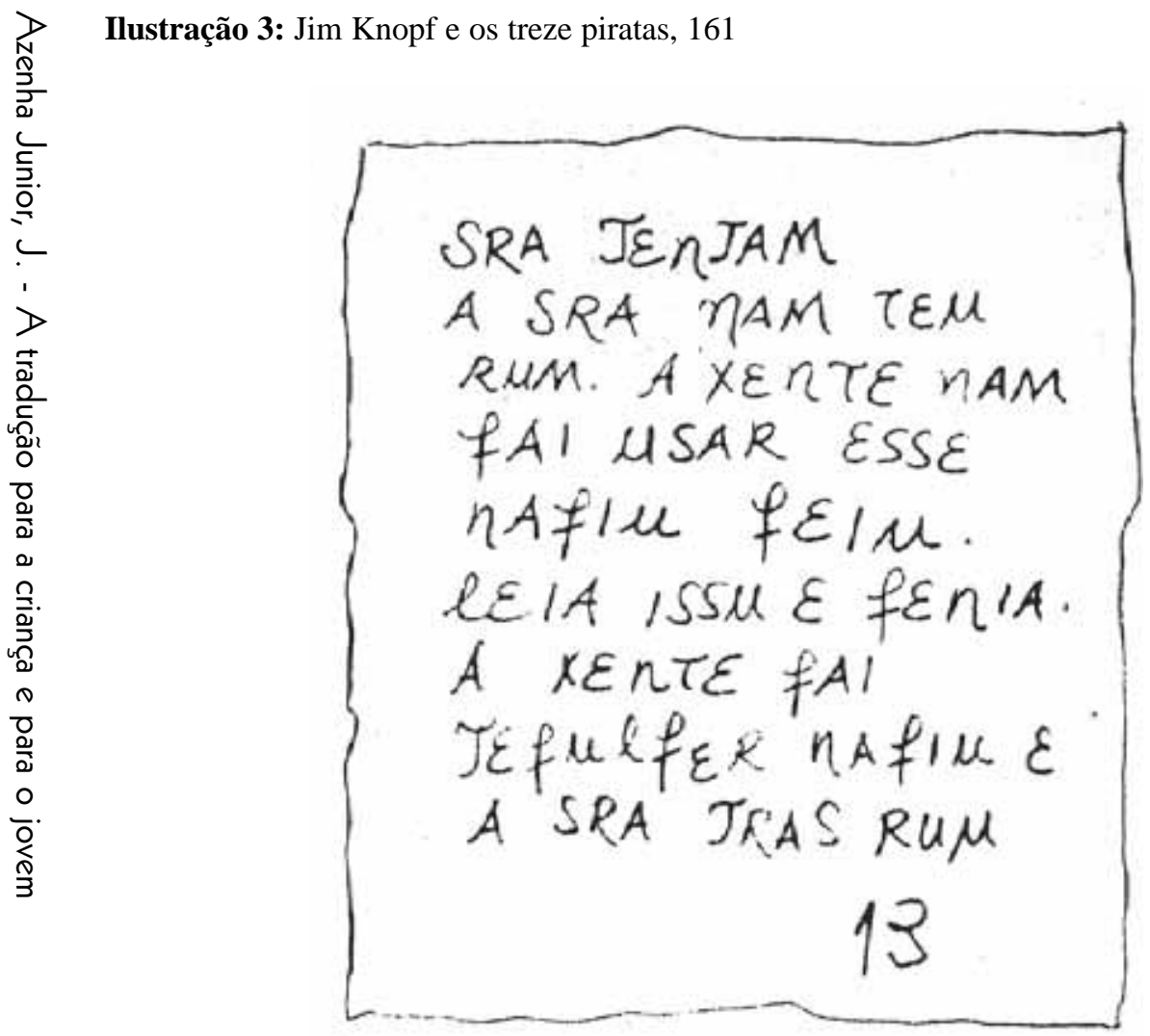

No primeiro exemplo, a personagem Robert visita a Alemanha dos anos de 1930 e depara-se com cartazes que, já na ascensão do Nazismo, conclamam o povo alemão a se insurgir contra os judeus. Nele, o espaço do cartaz, assim como a fonte das letras e sua disposição espacial, funcionam como elementos delimitadores de expansões ou de opções de tradução mais extensas e forçam uma versão quase interlinear, com pouca margem para a criatividade. Já no segundo exemplo, que ilustra um bilhete escrito pelos piratas de Jim Knopf e os treze piratas, de Michael Ende, as limitações são de diversas ordens: de um lado, o fato de que cada pirata só conhece uma letra do alfabeto - o que reduz a menos da metade as regras combinatórias para a formação de palavras - e a condicionante de que, embora pensem ser "treze", os piratas são, na verdade, apenas "doze", visto que um deles é o chefe do grupo - o que os leva, em suas limitações intelectuais, a "desdobrarem' este chefe em dois. Tudo isso sem contar, é claro, a questão da caligrafia, que transforma o bilhete num amontoado de garranchos. 


\section{Em síntese}

Neste artigo, a base da experiência foi o ponto de partida para uma breve reflexão sobre algumas questões envolvidas na tradução de textos escritos e traduzidos para jovens e crianças.

$\mathrm{Na}$ tentativa de se caracterizar esse gênero de textos, a observação mostrou que não se pode falar de um tipo de texto marcado por características textuais intrínsecas e recortado de seu entorno, mas sim de uma gama de variada diversidade, que define sua especificidade na interação com quem escreve, de um lado - o autor e o tradutor - e com quem lê, de outro - o tradutor (primeiro leitor), os agentes que tomam parte no processo de produção do livro e o público a que se visa.

A co-participação de vários agentes - e, porque não dizer, sua coresponsabilidade no resultado final - sugere o diálogo como a forma mais eficaz para se otimizarem os resultados, ao invés da consideração do processo de tradução de textos para jovens e crianças como um processo composto por etapas estanques. Tal atitude cooperativa, conforme se procurou demonstrar, encontra sua fundamentação também no aspecto controlador que a interação dos agentes tem sobre as projeções e as redes associativas desencadeadas pelas diferentes leituras.

Do ponto de vista do trabalho com os recursos lingüísticos em si, algumas das técnicas empregadas para se contornarem dificuldades comuns a esse gênero de textos - paráfrases, expansões, adaptações, reformulações, reescritura, simplificações, cortes e outros - têm conseqüências para as noções de criatividade e autoria em tradução: a tradução para o jovem e a criança surge, assim, como exemplo eloqüente de recriação e reescritura em tradução e demanda para si não apenas uma consideração mais sistemática por parte da teoria, mas também um tratamento diferenciado, no ambiente profissional, capaz de fazer jus à sua importância e complexidade. 


\section{Referências bibliográficas}

\section{Títulos de LIJ traduzidos pelo autor deste artigo ${ }^{14}$}

Breinholst, Willy. Ôi! Olha eu aqui! São Paulo, Martins Fontes 1984.

Breinholst, Willy. Ôi, mamãe! Ôi, papai! São Paulo, Martins Fontes 1984.

Breinholst, Willy. Minha mãe é a melhor do mundo! São Paulo, Martins Fontes 1984.

Breinholst, Willy. Veja só, mamãe! Veja só, papai! São Paulo, Martins Fontes 1984.

Breinholst, Willy. Êi, mamãe - O que está escrito aqui? São Paulo, Martins Fontes 1984.

Ende, Michael. Jim Knopf e os 13 piratas. São Paulo, Martins Fontes 1993.

Ende, Michael. Jim Knopf e Lucas, o maquinista. São Paulo, Martins Fontes 1989.

Ende, Michael. A história sem fim (Trad. Maria do Carmo Cary. Revisão e texto final João Azenha Junior). São Paulo, Martins Fontes 1985.

EndE, Michael. Die unendliche Geschichte. Stuttgart, K. Thienemanns Verlag 1979.

Enzensberger, Hans-Magnus. Por onde você andou, Robert? São Paulo, Companhia das Letras 1999.

Enzensberger, Hans-Magnus. Wo warst du, Robert? Munique/Viena, Carl Hanser Verlag 1998.

GaArder, Jostein. O dia do curinga. São Paulo, Companhia das Letras 1996.

GAARDER, Jostein. O mundo de Sofia. Romance da história da Filosofia. São Paulo, Companhia das Letras 1995.

HaCKE, Axel. O reiżinho Dežembro. São Paulo, Companhia das Letrinhas 1996.

HaCKe, Axel. Der kleine König Dezember. Munique, Verlag Antje Kunstmann 1993.

14 Nesta listagem, limito-me a citar a referência bibliográfica do título alemão, a partir do qual a tradução foi feita, apenas para as obras de que foram extraídos os exemplos apresentados no corpo deste trabalho. 
SCHLEgEl, Dorothea e Friedrich SCHLEgel. A bistória do mago Merlin. Martins Fontes, São Paulo 1989.

Sommer-Bodenburg, Ângela. A viagem do pequeno vampiro. São Paulo, Martins Fontes 1987.

Sommer-Bodenburg, Ângela. O pequeno vampiro em perigo. São Paulo, Martins Fontes 1987.

Sommer-Bodenburg, Ângela. O grande amor do pequeno vampiro. São Paulo, Martins Fontes 1987.

Sommer-Bodenburg, Angela. O pequeno vampiro. São Paulo, Martins Fontes 1986.

Sommer-Bodenburg, Ângela. O pequeno vampiro no sítio. São Paulo, Martins Fontes 1986.

Sommer-Bodenburg, Ângela. A mudança do pequeno vampiro. São Paulo, Martins Fontes 1986.

Sommer-Bodenburg, Angela. Der kleine Vampir und die grosse Liebe. Reinbeck bei Hamburg, Rowohlt Taschenbuch Verlag 1985.

Sommer-Bodenburg, Ângela. Der kleine Vampir auf dem Bauernhof. Reinbek bei Hamburg, Rowohlt Taschenbuch Verlag 1983.

\section{Referências citadas no corpo do texto}

Azenha Jr., João. "A tradução de literatura infanto-juvenil alemã e a redescoberta do prazer de escrever". In: RUNA - Revista Portuguesa de Estudos Germanísticos n ${ }^{\circ}$ 26, vol. II, Coimbra, Associação Portuguesa de Estudos Germanísticos (APEG) 1996, 705-710.

AzENHA Jr., João. "Minha experiência com a tradução de literatura infantojuvenil alemã". In: Cadernos da Semana de Literatura Alemã: A recepção da literatura alemã no Brasil, São Paulo, FFLCH/USP, 1991, 55-60.

Dias, Renata de Sousa. Traduziir para a criança: uma brincadeira muito séria. Dissertação de Mestrado, tomos I e II. São Paulo, FFLCH/USP 2001.

Lajolo, Marisa e Regina Zilbermann. Um Brasil para crianças. Para conhecer a literatura infantil brasileira: histórias, autores e textos. São Paulo, Global 1986. 
Lajolo, Marisa e Regina ZiLbermann. Literatura infantil brasileira: história e bistórias. São Paulo, Ática 1985.

Larenjeira, Mário. Poética da tradução: do sentido à significância (Série Criação e Crítica, v. 12). São Paulo, EDUSP/FAPESP 1993, 161.

Meireles, Cecília. Problemas da Literatura Infantil. Belo Horizonte, Publicações da Secretaria da Educação do Estado de Minas Gerais 1951.

Milton, John. "The Political Adaptations of Monteiro Lobato”. In: Tradução, Retradução e Adaptação, Cadernos de Tradução no XI, 2003/1. Florianópolis, Universidade Federal de Santa Catarina 2004, 211-227.

Milton, John. O Clube do Livro e a tradução. Bauru (SP), EDUSC 2002.

Oittinen, Riitta. "Kinderliteratur”. In: Snell-Hornby, Mary et al. (eds.): Handbuch Translation, Tübingen, Stauffenburg-Verlag 1998, 250-253.

Pomari, Gerson Luis. O pintor e o poeta: Wilhelm Busch no Brasil. Dissertação de Mestrado. São José do Rio Preto (SP), IBILCE/UNESP 1999.

STÖRIG, Hans Joachim (ed.). Das Problem des Übersetzens (2a. edição, revista e modificada; 1a. edição, 1963). Darmstadt, Wissenschaftliche Buchgesellschaft 1969.

VIEIRA, Adriana Silene. "Monteiro Lobato Translator". In: Emerging Views on Translation History in Brazil. CROP - Revista do Curso de Lingua Inglesa e Literaturas Inglesa e Norte-Americana da FFLCH-USP, nº 6. São Paulo, Humanitas 2001, 143-169. 